NBER WORKING PAPER SERIES

A MULTI-COUNTRY STUDY OF THE INFORMATION IN THE TERM STRUCTURE ABOUT FUTURE INFLATION

Frederic S. Mishkin

Working Paper No. 3125

NATIONAL BUREAU OF ECONOMIC RESEARCH

1050 Massachusetts Avenue

Cambridge, MA 02138

September 1989

Research support has been provided by the Faculty Research Fund of the Graduate School of Business, Columbia University. I thank Jae-Won Park for research assistance David Backus, Vance Roley, Maury Obstfeld and participants in seminars at Columbia, Cornell, Princeton and the NBER for their helpful comments. This paper is part of NBER's research programs in Financial Markets and Monetary Economics and Economic Fluctuations. Any opinions expressed are those of the author not those of the National Bureau of Economic Research. The data in this paper will be made available free of charge to any researcher who sends me a standard formatted $51 / 4^{*} 360 \mathrm{~KB}$ diskette with a stamped, selfaddressed envelope. 
NBER Working Paper \#3125

September 1989

\section{A MULTI-COUNTRY STUDY OF THE INFORMATION IN THE TERM STRUCTURE ABOUT FUTURE INFLATION}

\section{ABSTRACT}

This paper provides evidence on what the term structure (f or maturities of twelve months or less) tells us about future inflation in ten OECD countries. The empirical results on the information in the term structure contrast with those that find that the level of interest rates help forecast the future level of inflation. Instead, they indicate that for the majority of the countries in the sample, the term structure does not contain a great deal of inf ormation about the future path of inflation. The results for France, the United Kingdom and Germany tell a different story; however. In these countries the term structure contains a higbly significant amount of inf ormation about future cbanges in inflation.

The evidence in this paper suggests tbat central banks for most of the countries studied here sbould exercise some caution in using the term structure of interest rates as a guide for assessing inflationary pressures in the economy, as is currently under consideration by the U.S. central bank. Altbougb there is significant information in the term structure about the future path of inflation for a few of the countries, this is not a result that is true in general.

The empirical evidence does reveal, however, that for every country studied except tbe United Kingdom, there is a great deal of information in the term structure of nominal interest rates about the term structure of real interest rates. This finding is an extremely useful one because it suggests tbat for most countries researcbers can examine observable data on the nominal term structure to provide them with information about the bebavior of the real term structure.

Frederic S. Mishkin

Graduate School of Business

Uris Hall 619

Columbia University

(212) $280-3488$ 


\section{Introduction}

In recent years, central banks of many countries have increasingly focused on the goal of price stability. In pursuing this goal, central banks need inf ormation on the degree of inflationary pressures in the economy, and one natural place to look for this information is the term structure of interest rates. Research beginning with Fama (1975) of tenf inds that the level of interest rates helps forecast future inflation, 'while recent research has focused on the information in the term structure aboutf uture interest rate movements. ${ }^{2}$ These two lines of research suggest that the term structure of interest rates might contain information about the future path of inflation.

One reason why the information in the term structure about future inflation requires careful study is that it bears directly on whether central banks should use the term structure as a guide for monetary policy, as has recently been advocated by the Vice-Chairman of the Board of Governors of the Federal Rtustve. A second reason is that empirical evidence on this topic can tell us whether movements in the term structure of ceal interest rates (which is not directly observable) are revealed by movements in the term structure of nominal interest rates (which is observable). The term structure of real interest rates has an important role in understanding asset pricing and in theories of the business cycle and so is of much concern to theorists. Finding out whether observable data on the nominal term structure provides information about the behavior of the real term structure can thus help guide theoretical research.

This paper examines empirically what the term structure of interest rates tells us about future inflation in the United States and in nine other OECD countries using euro market data.

'For example, Nelson and Schwert (1977), Mishkin (1981, 1984), Fama and Gibbons (1982), and Huizinga and Mishkin (1986).

${ }^{2}$ For example, Shiller, Campbell and Schoenholtz (1982) and Mankiw and Summers (1984) have questioned the value of the term structure in predicting future short-term interest rates, while recent evidence in Fama (1984), Fama and Bliss (1987), Campbell and Shiller (1987), Hardouvelis (1988) and Mishkin (1988a) is more positive about the ability of the term structure to forecast future interest rates. 
Earlier research, Mishkin (1988b), has examined the information in the term structure about future inf lation in the U.S. using Treasury bill rate data. However, there are several reasons why a multi-country empirical analysis of the information in the term structure about future inflation is needed. Assessing future inflationary pressures in the economy is a concern of central banks in all the countries studied here. Thus learning about the ability of the term structure to forecast the future path of inflation in each of these countries is important knowledge for their central bankers to have because it will help them decide whether using the term structure as a guide for monetary policy is a sensible strategy. It is also worth examining what the term structure tells us about future inflation in other countries besides the U.S. because it will provide us with clues about how the information in the term structure might change with different monetary regimes. Different countries do provide different conclusions on the relationship between inflation and interest rates, ${ }^{3}$ and so it is plausible that the information in the term structure might differ substantially across countries. A final rea son for examining data in other countries is that it will provide further information on which results found for the United States are robust across countries. This is also important because the inf ormation in the term structure in the U.S. may be representative of only one type of monetary regime and a change in the regime may alter the inf ormation in the term structure. Finding that certain results tend to be true for other countries, should make U.S. policymakers more secure about conclusions derived from U.S. data.

\section{The Methodology}

The main focus of the paper is on estimates of a forecasting equation that tell us whether the term structure helps to predict the future path of inflation. This equation, which will be referred to as the "inflation change equation", is a regression of the change in the future m-period inflation rate from the n-period inflation rate $\left(\pi_{i}^{*}-\pi_{l}^{*}\right)$ on the "slope" of the term structure $\left(i_{1}^{*}\right.$ -

'For example, see Mishkin (1984). 
$\left.\mathrm{i}^{\prime}\right)$.

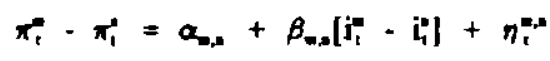

Tests of the statistical significance of the $\beta_{\boldsymbol{*}}$ coefficient and whether it diff ers from 1.0 reveal how much information there is in the slope of the term structure about future changes in inflation. More specifically, as is described in Mishkin [1988b], a statistical rejection of $\beta_{a, \ldots}=0$ provides evidence that 1) the term structure contains significant inf ormation about the future path of inflation, and 2) the slopes of the term structures of real and nominal interest rates do not move one-for-one with each other. On the other band, a statistical rejection of $\beta_{2,}=1$ provides evidence that 1) the slope of the real term structure is not constant over time, and 2) the term structure of nominal interest rates provides inf ormation about the term structure of real interest rates.

Note that the phrase "inf ormation in the term structure" is being used in this paper quite narrowly. Information in the term structure about the path of future inflation refers only to the ability of the slope, $i_{t}^{*}-i_{i}^{0}$ to predict the change in the inflation rate, $\pi_{t}^{*}-\pi_{t}^{*}$. This paper focuses on the predictive power of the slope term, $i_{i}^{*}-i_{t}^{i}$, because it is the most natural piece of inf ormation in the term structure to examine. Tests of the statistical significance of the $\beta_{\text {. }}$ coefficient and whether it differs from one reveal how much information there is in the slope of the term structure about future changes in inflation.

Before going on to a discussion of the data and the empirical results, several additional econometric issues that have import ant consequences for by pothesis testing aeed to be discussed. One important econometric consideration is that the error term $\eta_{i}^{*-\infty}$ exhibits serial correlation which readers OLS standard errors invalid. One source of the serial correlation arises from the use here of overlapping data in which $\mathbf{m}>1--$ i.e., the number of periods for the interest rate and the inflation rate are greater than the observation interval. As is well known, this leads to 
correlation of the error term with up to m-1 of its lagged values. Furthermore, as is explained in Mishkin (1988b), additional serial correlation in $\eta_{\imath}^{-1}$ can stem from serial correlation of real interest rates. Examination of the residual autocorrelations revealed that $\eta_{1}^{-1}$ often has significant correlation with its values lagged more than m-1 periods, especially for countries other than the United States. Valid standard errors are generated using the method outlined by Hansen and Hodrick (1980), with a modif ication due to Hansen (1982) that allows for conditional heteroscedasticity and a modification by Newey and West (1987) that insures the variancecovariance matrix is positive definite by imposing linearly declining weights on autocovariance matrices. The standard errors reported in the tables are constructed allowing for non-zero autocorrelations going back three years ( 36 periods) which is enough to capture the serial correlation revealed in the data.'

Additional information is available in the term structure that is not being used in ordinary least squares estimation because contemporaneous errors in forecasting inflation for different horizons may be highly correlated. Therefore, seemingly unrelated regression (SUR) estimates of a system of equations with different horizons may produce substantial gains in efficiency." The

The Hansen (1982) modification is the same numerically as that proposed by White (1980). White's results are obtained with unconditional heteroscedasticity rather than conditional heteroscedasticity, but additional assumptions are required.

'I also estimated the standard errors for each equation allowing only for non-zero autocorrelations going back $\mathbf{m}-1$ periods and the results were not appreciably affected.

"There are two ways to think about the inflation change forecasting equation and hence about the consistency of SUR estimated coefficients. If the forecasting equation is just viewed as a projection equation in which the error term is by construction orthogonal to the $i_{i}^{*}-i_{1}^{\prime}$ regressor, then consistency of the SUR estimates requires an additional assumption that the $i_{c}^{*} \cdot i_{p}^{i}$ in each equation is uncorrelated with all the error terms. As described in Mishkin (1988b), an alternative way of viewing the inflation change equation is as a test for $\beta_{a}=1$. With this interpretation, the same conditions that produce consistency for OLS estimates of $\beta_{-.}=1 \ldots$ the constancy of the real rate differentials, rr; - rr; -- also produce consistency of the SUR estimates. Constancy of the real rate differentials implies that the error terms just equal the difference between the forecast errors of inflation at the $\mathbf{m}$ and $\mathbf{q}$ horizon. Since under rational expectations these forecast errors are uncorrelated with all inf ormation available at time $t$, which includes $i_{\mathrm{f}}^{*}$ for all $m$, constancy of the real rate differentials implies the condition for consistency of the SUR estimates, that all of the explanatory variables in the equations are orthogonal to all the error terms. 
SUR standard error estimates will again be incorrect because of the serial correlation of the error terms. The Hansen-Hodrick, Newey-West estimate of the variance-covariance matrix allowing for conditional heteroscedasticity can be generalized to apply to a seemingly unrelated regression system of $g$ equations as follows. The SUR estimation method assumes that the variancecovariance matrix of the residuals is $\Sigma \otimes \mathrm{I}_{\mathrm{T}}$, where,

$$
\begin{aligned}
\Sigma \quad= & \text { variance-covariance matrix of the contemporaneous residuals from the } g \\
& \text { equations, } \\
I_{T} \quad= & T \times T \text { identity matrix, where } T \text { is the number of observations. }
\end{aligned}
$$

Using the Choleski decomposition $\Sigma^{-1}=$ P'P, we get the GLS (i.e., the SUR) estimates by premultiplying the system by $P \otimes I_{T}$ and then proceed with OLS estimation. Allowing for conditional heteroscedasticity, the Hansen-Hodrick variance-covariance matrix of the parameter estimates of the transf ormed system is then,

$$
V=(\tilde{\mathbf{X}} \cdot \tilde{\mathbf{X}})^{-1} E[\tilde{\mathbf{X}} \cdot \tilde{\eta} \tilde{\eta} \cdot \tilde{\mathbf{X}}](\tilde{\mathbf{X}} \cdot \tilde{\mathbf{X}})^{-1}
$$

where,

$V \quad=$ variance covariance matrix of estimated coefficients.

$\mathrm{x}=\left[\begin{array}{cccccc}\mathrm{x}^{2} & 0 & . & . & . & 0 \\ 0 & \mathrm{x}^{2} & 0 & . & . & 0 \\ . & & & & & \\ \cdot & & & & & \\ 0 & . & . & . & 0 & \mathrm{x}\end{array}\right]$

$X^{\prime}=$ the matrix of explanatory variables for the $i$ th equation,

$\tilde{x}=\left(P \otimes I_{T}\right) X$, 


$$
\begin{aligned}
& \tilde{n}=\left(\mathrm{POl}_{\tau}\right) \eta \\
& E[\ldots]=\text { the expectations operator. }
\end{aligned}
$$

Writing the variance-covariance matrix out results in

$$
V=\left(X^{\prime}\left(P^{\prime} \otimes L_{\tau}\right)\left(P \otimes L_{\tau}\right) X\right)^{-1} E\left[X^{\prime}\left(P^{\prime} \otimes L_{\tau}\right)\left(P \otimes L_{\tau}\right) \eta \eta^{\prime}\left(P^{\prime} \otimes L_{\tau}\right)\left(P \otimes L_{\tau}\right) X\right]\left(X^{\prime}\left(P^{\prime} \otimes L_{\tau}\right)\left(P \otimes L_{\tau}\right) X\right)^{\prime \prime}
$$

Making use of the fact that $P^{\prime} P=\Sigma^{-1}$, the variance-covariance matrix $f$ or the SUR estimates, which is corrected for serial correlation both within and across equations and allows for conditional heteroscedasticity, can be rewritten as,

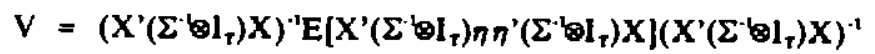

with the $j, k$ (where $j$ and $k$ reference equations) block of the $E\left[X^{\prime}\left(\Sigma^{\prime} \otimes L_{\tau}\right) \eta \eta^{\prime}\left(\Sigma^{\prime} \otimes L_{\tau}\right) X\right]$ matrix using the Newey. West procedure estimated as'

$$
\sum_{i=-q}^{q} \sum_{t=1}^{T}[1-i /(q+1)] x_{i} \cdot \hat{\eta}_{t, i} \hat{\eta}_{t-i}
$$

where,

$q=$ the order of the MA process for the error terms in the system.

\footnotetext{
'Note that the presence of $\eta \eta$ ' in the formula for the variance-covariance matrix in (4) takes account of serial correlation of the error terms both within an equation and across equations as well as for conditional heteroscedasticity in these covariances. Thus even though SUR estimation only takes account of contemporaneous correlation of error terms across equations, the variancecovariance matrix above is corrected for serial correlation both within and across equations as well as for conditional heteroscedasticity.
} 
Now that we have completed our discussion of the econometric details, we can go on to discuss the data used in the empirical analysis.

\section{The Data}

The empirical analysis makes use of monthly data on inflation rates and one, three, six, and twelve-month interest rates in the euro deposit market for the following ten OECD countries: United States, Canada, United Kingdom, Belgium, France, Germany, Italy, Netherlands, Switzerland and Japan. For every country except Japan, the sample period extends from the beginning of the floating rate period, April 1973, to December 1986.' However, the data for Japan is unavailable until October 1975, so the sample period for Japan starts in October 1975. The inf lation data for these count ries are sea sonally unadjusted CPI measures obtained from the International Financial Statistics (IFS) tape maintained by the International Monetary Fund with the exception of the U.S. data. Because of the well known problems with the treatment of housing costs in the U.S. CPI before 1983, the U.S. inflation data is calculated from a CPI series which appropriately treats housing costs on a rental-equivalence basis throughout the sample period. For more details on this series see Huizinga and Mishkin (1984, 1986). The euro.market data have been obtained from the Harris Bank tape maintained at the NYU Business School and are used in this study for several reasons." High quality data for domestic interest rates are not as readily available for other countries besides the United States and Canada. In some of the other countries, domestic Treasury bill rates are not always market clearing, so that these data, although sometimes available, do not reflect the true cost of credit. Euro rates, however, are

\footnotetext{
Note that with a sample period ending in December 1986, inflation data for the year 1987 is required.

'In the few cases where euro rate data were missing, the euro rate was calculated from the interest parity condition. The rest of the data were checked by verifying that there were no large deviations from interest parity. Several obvious errors in the tape were found in this manner and were corrected.
} 
market clearing. In addition, euro deposits denominated in different currencies are issued by banks that have similar default risks, ${ }^{10}$ and they are not subject to capital controls because they are of shore securities. This makes the term structures of different countries comparable because they will not have to be adjusted for differing default risks or non-comparability because of capital controls. Both the interest rates and inflation data are expressed on a continuously compounded basis at an annual rate in percent.

The timing of the variables is as follows. A January interest rate observation uses the euro rate data for the last Friday of December. A January observation for a one-month inflation rate is calculated from the December and January CPI data; a three-month inflation rate from the December and March CPI data; and so on.

\section{The Empirical Results}

Table 1 contains the estimates of the inf lation-change forecasting equations which regress the change in the future $m$-period inflation rate from the $n$-period inflation rate $\left(\pi_{i}^{*}-\pi_{i}^{*}\right)$ on the "slope" of the term structure $\left(i,-i i_{l}^{2}\right)$. In contrast to previous research which has found that the level of interest rates contains a great deal of inf ormation about the level of future inflation, there is less evidence in Table 1 that the slope of the term structure provides information about the future path of inflation. The $\beta_{n}$, coeff icients are statistically signif icant only one-third of the time and are not always positive (almost one-quarter of them are negative).

The United States displays aegative as well as positive $\beta_{\text {., }}$ coefficients for horizons less

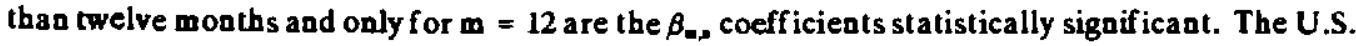
results thus suggest that the shortest end of the term structure (maturities of six months or less)

\footnotetext{
"The euro deposit rates are collected from quotes by the Harris Bank in the case of euro dollars and by other banks that specialize in issuing euro deposits in other currencies. The fact that interest parity holds fairly tightly in the data here indicates that the risk premiums are very similar for the differeat banks quoting the euro deposit rates.
} 
Table 1

Estimates of Inflation Change Equations"

$\pi_{t}^{n}-\pi_{t}^{n}=\alpha_{0, n}+\beta_{1, n}\left[i_{i}^{n}-i_{i}^{n}\right]+\eta_{t}^{n, n}$

\begin{tabular}{|c|c|c|c|c|c|c|}
\hline$\underset{\text { (months) }}{\mathbf{m}, \mathbf{n}}$ & $\alpha_{\mathbf{m}, n}$ & $\beta_{a, n}$ & $\mathrm{R}^{2}$ & SE & $\begin{array}{c}t-\text { test } \\
\text { of } \\
\beta_{., n}=0\end{array}$ & $\begin{array}{c}t-t e s t \\
o f \\
a_{., n}-1\end{array}$ \\
\hline
\end{tabular}

Country: UNITED STATES

\begin{tabular}{|c|c|c|c|c|c|c|}
\hline 3,1 & $\begin{array}{c}0.0121 \\
(0.0552)\end{array}$ & $\begin{array}{l}-0.3166 \\
(0.2437)\end{array}$ & 0.005 & 2.145 & -1.30 & $5.40^{\star \star}$ \\
\hline 6,1 & $\begin{array}{l}-0.0522 \\
(0.1324)\end{array}$ & $\begin{array}{c}0.0995 \\
(0.1785)\end{array}$ & 0.001 & 2.620 & 0.56 & $5.05^{\star \star}$ \\
\hline 12,1 & $\begin{array}{l}-0.0679 \\
(0.2247)\end{array}$ & $\begin{array}{c}0.3339 \\
(0.1340)\end{array}$ & 0.022 & 2.735 & $2.49^{\star}$ & $4.97^{\star \star}$ \\
\hline 6,3 & $\begin{array}{l}-0.0422 \\
(0.0801)\end{array}$ & $\begin{array}{r}0.2547 \\
(0.3260\end{array}$ & 0.006 & 1.359 & 0.78 & $2.49^{\star}$ \\
\hline 12,3 & $\begin{array}{l}-0.0075 \\
(0.1814)\end{array}$ & $\begin{array}{c}0.4514 \\
(0.2094)\end{array}$ & 0.059 & 1.726 & $2.16^{\star}$ & $2.62^{\star \star}$ \\
\hline 12,6 & $\begin{array}{c}0.0441 \\
(0.1300)\end{array}$ & $\begin{array}{c}0.4316 \\
(0.1603)\end{array}$ & 0.057 & 1.054 & $2.69^{\star \star}$ & $3.55^{\star \star}$ \\
\hline
\end{tabular}

Country: CANADA

\begin{tabular}{|c|c|c|c|c|c|c|}
\hline 3,1 & $\begin{array}{l}-0.0655 \\
(0.0688)\end{array}$ & $\begin{array}{c}0.2881 \\
(0.3293)\end{array}$ & 0.001 & 3.114 & 0.87 & $2.16^{\star}$ \\
\hline 6,1 & $\begin{array}{l}-0.1067 \\
(0.1267)\end{array}$ & $\begin{array}{c}0.0035 \\
(0.1768)\end{array}$ & 0.000 & 3.379 & 0.02 & $5.63^{\star \star}$ \\
\hline 12,1 & $\begin{array}{l}-0.1920 \\
(0.2291)\end{array}$ & $\begin{array}{l}-0.0096 \\
(0.1487)\end{array}$ & 0.000 & 3.655 & -0.06 & $6.79^{\star \star}$ \\
\hline 6,3 & $\begin{array}{l}-0.0569 \\
(0.0783)\end{array}$ & $\begin{array}{l}-0.2710 \\
(0.2395)\end{array}$ & 0.006 & 1.473 & -1.13 & $5.31^{\star \star}$ \\
\hline 12,3 & $\begin{array}{l}-0.1850 \\
(0.2036)\end{array}$ & $\begin{array}{l}-0.1547 \\
(0.2454)\end{array}$ & 0.004 & 1.940 & -0.63 & $4.71^{\star \star}$ \\
\hline 12,6 & $\begin{array}{l}-0.1236 \\
(0.1544)\end{array}$ & $\begin{array}{l}-0.1347 \\
(0.2361)\end{array}$ & 0.003 & 1.199 & -0.57 & $4.81^{\star \star}$ \\
\hline
\end{tabular}




\begin{tabular}{|c|c|c|c|c|c|c|}
\hline Country: & UNITED KI & GDOM & & & & \\
\hline 3,1 & $\begin{array}{l}-0.0834 \\
(0.1342)\end{array}$ & $\begin{array}{c}0.5229 \\
(0.6339)\end{array}$ & 0.002 & 6.491 & 0.82 & 0.75 \\
\hline 6,1 & $\begin{array}{l}-0.0035 \\
(0.3245)\end{array}$ & $\begin{array}{c}0.7434 \\
(0.5213)\end{array}$ & 0.010 & 7.763 & 1.43 & 0.49 \\
\hline 12,1 & $\begin{array}{c}0.2039 \\
(0.6214)\end{array}$ & $\begin{array}{c}1.0072 \\
(0.3186)\end{array}$ & 0.031 & 8.224 & $3.16^{\star \star}$ & -0.02 \\
\hline 6,3 & $\begin{array}{c}0.0817 \\
(0.2493)\end{array}$ & $\begin{array}{c}0.7328 \\
(0.5853)\end{array}$ & 0.009 & 3.857 & 1.25 & 0.46 \\
\hline 12,3 & $\begin{array}{c}0.2881 \\
(0.4890)\end{array}$ & $\begin{array}{c}0.9934 \\
(0.2520)\end{array}$ & 0.039 & 5.141 & $3.94^{\star \star}$ & 0.03 \\
\hline 12,6 & $\begin{array}{c}0.1655 \\
(0.2537)\end{array}$ & $\begin{array}{c}0.9798 \\
(0.3388)\end{array}$ & 0.042 & 3.053 & $2.89^{\star \star}$ & 0.06 \\
\hline
\end{tabular}

Country: BELGIUM

\begin{tabular}{|c|c|c|c|c|c|c|}
\hline 3,1 & $\begin{array}{l}-0.0571 \\
(0.1250)\end{array}$ & $\begin{array}{c}0.5829 \\
(0.9746)\end{array}$ & 0.006 & 3.041 & 0.60 & 0.43 \\
\hline 6,1 & $\begin{array}{l}-0.0349 \\
(0.1720)\end{array}$ & $\begin{array}{l}-0.0131 \\
(0.5380)\end{array}$ & 0.000 & 3.392 & -0.02 & 1.88 \\
\hline 12,1 & $\begin{array}{l}-0.1298 \\
(0.3411)\end{array}$ & $\begin{array}{c}0.0353 \\
(0.3447)\end{array}$ & 0.000 & 3.793 & 0.10 & $2.80^{\star \star}$ \\
\hline 6,3 & $\begin{array}{l}-0.0340 \\
(0.1116)\end{array}$ & $\begin{array}{l}-0.0846 \\
(0.1760)\end{array}$ & 0.001 & 1.653 & -0.48 & $6.16^{\star \star}$ \\
\hline 12,3 & $\begin{array}{l}-0.1143 \\
(0.3201)\end{array}$ & $\begin{array}{c}0.0466 \\
(0.2329)\end{array}$ & 0.000 & 2.213 & 0.20 & $4.09^{\star \star}$ \\
\hline 12,6 & $\begin{array}{l}-0.1068 \\
(0.2059)\end{array}$ & $\begin{array}{l}-0.0096 \\
(0.2898)\end{array}$ & 0.000 & 1.287 & -0.03 & $3.48^{\star \star}$ \\
\hline
\end{tabular}




\begin{tabular}{|c|c|c|c|c|c|c|}
\hline Country: & FRANCE & & & & & \\
\hline 3,1 & $\begin{array}{l}-0.0816 \\
(0.0886)\end{array}$ & $\begin{array}{c}0.3863 \\
(0.0915)\end{array}$ & 0.054 & 2.183 & $4.22^{\star *}$ & $6.71^{\star \star}$ \\
\hline 6,1 & $\begin{array}{l}-0.1150 \\
(0.1518)\end{array}$ & $\begin{array}{c}0.3256 \\
(0.0623)\end{array}$ & 0.062 & 2.660 & $5.23^{\star \star}$ & $10.82^{\star \star}$ \\
\hline 12,1 & $\begin{array}{l}-0.1377 \\
(0.2630)\end{array}$ & $\begin{array}{c}0.2700 \\
(0.0718)\end{array}$ & 0.063 & 2.873 & $3.76^{\star *}$ & $10.17^{* \star}$ \\
\hline 6.3 & $\begin{array}{l}-0.0462 \\
(0.0803)\end{array}$ & $\begin{array}{c}0.2319 \\
(0.0701)\end{array}$ & 0.029 & 1.316 & $3.31^{\star \star}$ & $10.95^{\star *}$ \\
\hline 12,3 & $\begin{array}{l}-0.0913 \\
(0.2306)\end{array}$ & $\begin{array}{c}0.2394 \\
(0.1328)\end{array}$ & 0.052 & 1.828 & 1.80 & $5.73^{\star *}$ \\
\hline 12,6 & $\begin{array}{l}-0.0237 \\
(0.1777)\end{array}$ & $\begin{array}{c}0.2910 \\
(0.1865)\end{array}$ & 0.057 & 1.117 & 1.56 & $3.80^{\star \star}$ \\
\hline
\end{tabular}

Country: GERMANY

\begin{tabular}{|c|c|c|c|c|c|c|}
\hline 3.1 & $\begin{array}{l}-0.0649 \\
(0.0648)\end{array}$ & $\begin{array}{c}0.5959 \\
(0.3219)\end{array}$ & 0.009 & 2.460 & 1.85 & 1.26 \\
\hline 6,1 & $\begin{array}{l}-0.1062 \\
(0.1242)\end{array}$ & $\begin{array}{c}0.3523 \\
(0.2094)\end{array}$ & 0.006 & 3.024 & 1.68 & $3.09^{\star \star}$ \\
\hline 12,1 & $\begin{array}{l}-0.2122 \\
(0.2024)\end{array}$ & $\begin{array}{c}0.3420 \\
(0.1098)\end{array}$ & 0.012 & 3.137 & $3.11^{\star \star}$ & $5.99^{\star \star}$ \\
\hline 6,3 & $\begin{array}{l}-0.0390 \\
(0.0693)\end{array}$ & $\begin{array}{c}0.0414 \\
(0.2775)\end{array}$ & 0.000 & 1.596 & 0.15 & $3.45^{\star \star}$ \\
\hline 12,3 & $\begin{array}{l}-0.1627 \\
(0.1616)\end{array}$ & $\begin{array}{c}0.3071 \\
(0.1523)\end{array}$ & 0.011 & 2.093 & $2.02^{\star}$ & $4.55^{\star \star}$ \\
\hline 12,6 & $\begin{array}{l}-0.1116 \\
(0.1132)\end{array}$ & $\begin{array}{c}0.5418 \\
(0.2310)\end{array}$ & 0.030 & 1.308 & $2.35^{\star}$ & $1.98^{\star}$ \\
\hline
\end{tabular}




\begin{tabular}{|c|c|c|c|c|c|c|}
\hline Country: & ITALY & & & & & \\
\hline 3,1 & $\begin{array}{l}-0.0589 \\
(0.1120)\end{array}$ & $\begin{array}{l}-0.2659 \\
(0.1309)\end{array}$ & 0.007 & 4.443 & $-2.03^{\star}$ & $9.67^{\star *}$ \\
\hline 6.1 & $\begin{array}{l}-0.1183 \\
(0.2323)\end{array}$ & $\begin{array}{l}-0.0621 \\
(0.1111)\end{array}$ & 0.001 & 5.514 & -0.56 & $9.56^{* *}$ \\
\hline 12,1 & $\begin{array}{c}0.0131 \\
(0.4920)\end{array}$ & $\begin{array}{c}0.1880 \\
(0.1036)\end{array}$ & 0.009 & 6.013 & 1.81 & $7.84^{\star *}$ \\
\hline 6,3 & $\begin{array}{l}-0.0009 \\
(0.1363)\end{array}$ & $\begin{array}{c}0.1876 \\
(0.0944)\end{array}$ & 0.006 & 2.945 & $1.99^{*}$ & $8.61^{* *}$ \\
\hline 12,3 & $\begin{array}{c}0.4276 \\
(0.5092)\end{array}$ & $\begin{array}{c}0.5346 \\
(0.1724)\end{array}$ & 0.075 & 3.883 & $3.10^{* \star}$ & $2.70^{\star *}$ \\
\hline 12.6 & $\begin{array}{c}0.5129 \\
(0.4594)\end{array}$ & $\begin{array}{c}0.7635 \\
(0.3043)\end{array}$ & 0.118 & 2.267 & $2.51^{\star}$ & 0.78 \\
\hline
\end{tabular}

Country: NETHERLANDS

\begin{tabular}{|c|c|c|c|c|c|c|}
\hline 3,1 & $\begin{array}{l}-0.1752 \\
(0.1050)\end{array}$ & $\begin{array}{c}0.0875 \\
(0.5900)\end{array}$ & 0.000 & 4.078 & 0.15 & 1.55 \\
\hline 6,1 & $\begin{array}{l}-0.2086 \\
(0.1596)\end{array}$ & $\begin{array}{l}-0.0179 \\
(0.5103)\end{array}$ & 0.000 & 4.619 & -0.04 & $1.99^{\star}$ \\
\hline 12,1 & $\begin{array}{l}-0.3293 \\
(0.2203)\end{array}$ & $\begin{array}{c}0.0275 \\
(0.3495)\end{array}$ & 0.000 & 4.739 & 0.08 & $2.78^{\star \star}$ \\
\hline 6,3 & $\begin{array}{l}-0.0416 \\
(0.0877)\end{array}$ & $\begin{array}{c}0.0025 \\
(0.2959)\end{array}$ & 0.000 & 2.561 & 0.01 & $3.37^{* *}$ \\
\hline 12,3 & $\begin{array}{l}-0.1588 \\
(0.1956)\end{array}$ & $\begin{array}{c}0.1692 \\
(0.1311)\end{array}$ & 0.004 & 2.760 & 1.29 & $6.34^{* \star}$ \\
\hline 12,6 & $\begin{array}{l}-0.1109 \\
(0.1212)\end{array}$ & $\begin{array}{c}0.1455 \\
(0.1234)\end{array}$ & 0.007 & 0.922 & 1.18 & $6.93^{\star *}$ \\
\hline
\end{tabular}


Country: SWITZERLAND

\begin{tabular}{|c|c|c|c|c|c|c|}
\hline 3,1 & $\begin{array}{l}-0.0276 \\
(0.1395)\end{array}$ & $\begin{array}{c}0.1184 \\
(0.3690)\end{array}$ & 0.000 & 3.813 & 0.32 & $2.39^{\star}$ \\
\hline 6,1 & $\begin{array}{c}0.2670 \\
(0.2101)\end{array}$ & $\begin{array}{l}-0.5338 \\
(0.3596)\end{array}$ & 0.006 & 4.728 & -1.48 & $4.27^{\star \star}$ \\
\hline 12,1 & $\begin{array}{l}-0.0742 \\
(0.3235)\end{array}$ & $\begin{array}{l}-0.2668 \\
(0.2754)\end{array}$ & 0.003 & 4.836 & .0 .97 & $4.60^{\star \star}$ \\
\hline 6.3 & $\begin{array}{c}0.1647 \\
(0.1193)\end{array}$ & $\begin{array}{l}-0.7804 \\
(0.3389)\end{array}$ & 0.016 & 2.412 & $-2.30^{\star}$ & $5.25^{\star \star}$ \\
\hline 12,3 & $\begin{array}{l}-0.1631 \\
(0.2657)\end{array}$ & $\begin{array}{l}0.2588 \\
(0.2723)\end{array}$ & 0.005 & 2.957 & -0.95 & $4.62^{\star \star}$ \\
\hline 12,6 & $\begin{array}{l}-0.1936 \\
(0.1846)\end{array}$ & $\begin{array}{c}0.0767 \\
(0.2863)\end{array}$ & 0.000 & 1.722 & 0.27 & $3.22^{\star \star}$ \\
\hline
\end{tabular}

Country: JAPAN

\begin{tabular}{|c|c|c|c|c|c|c|}
\hline 3.1 & $\begin{array}{l}-0.7235 \\
(0.4345)\end{array}$ & $\begin{array}{c}2.9616 \\
(1.2863)\end{array}$ & 0.056 & 6.923 & $2.30^{\star}$ & -1.52 \\
\hline 6,1 & $\begin{array}{l}-0.6336 \\
(0.4717)\end{array}$ & $\begin{array}{c}1.7293 \\
(0.5475)\end{array}$ & 0.044 & 7.212 & $3.16^{\star \star}$ & -1.33 \\
\hline 12.1 & $\begin{array}{l}-0.5186 \\
(0.4032)\end{array}$ & $\begin{array}{c}1.0314 \\
(0.3074)\end{array}$ & 0.028 & 7.647 & $3.36^{\star \star}$ & -0.10 \\
\hline 6,3 & $\begin{array}{l}-0.0451 \\
(0.0941)\end{array}$ & $\begin{array}{c}0.2564 \\
(0.3915)\end{array}$ & 0.001 & 3.204 & 0.65 & 1.90 \\
\hline 12,3 & $\begin{array}{l}-0.1938 \\
(0.1886)\end{array}$ & $\begin{array}{c}0.1594 \\
(0.3008)\end{array}$ & 0.002 & 3.628 & 0.53 & $2.79^{\star \star}$ \\
\hline 12,6 & $\begin{array}{l}-0.1569 \\
(0.1366)\end{array}$ & $\begin{array}{c}0.1523 \\
(0.3006)\end{array}$ & 0.002 & 1.702 & 0.51 & $2.82^{\star \star}$ \\
\hline
\end{tabular}

$\pi_{i}^{*}-\pi_{t}^{*}=$ difference between the m-period inflation rate from time $₫$ to $\downarrow+m$ and the $n$-period inflation rate from $\downarrow$ to $t+n$. $i_{\imath}^{n}-i_{i}^{p}=$ difference between the m-period nominal interest rate and the $n$ period nominal interest rate at time $\downarrow$. Standard errors of coefficients in parentheses. SE = standard error of the regression. ${ }^{*}=$ significant at the $5 \%$ level. ${ }^{*}=$ significant at the $1 \%$ level.

The sample period for Japan starts in October 1975 , the first date that data is available. 
provides no inf ormation about future inflation, while around maturities of twelve months, there is some information in the term structure about future changes in inflation. These results are consistent with those found with U.S. Treasury bill data in Mishkin (1988b), although Treasury bill data indicates stronger forecasting ability for the spread between twelve-month and sixmonth rates than do euro rate data.

The somewhat stronger ability of Treasury bill rates to forecast future changes in inflation suggests that the euro rate results in Table 1 may even understate somewhat the inf ormation in the term structure of domestic interest rates for the future path of inflation." As is pointed out in Mishkin (1984), euro rates bear a substantial risk premium over Treasury bill rates because. in contrast to Treasury securities, which are riskless in nominal terms, euro deposits are subject to delault risk since their issuing bank might fail. Indeed, this default risk premium is very variable and has at times exceeded five percentage points. Fluctuations in this risk premium in the euro rates are likely to obscure some of the ability of the term structure of euro rates to forecast the future path of inflation, and this is exactly what we find for U.S. data.

The United Kingdom, France, Germany, Italy and Japan also display information about the future path of inflation in the term structure, with the evidence for significant forecasting ability of the term structure strongest for France and the United Kingdom. For France and the

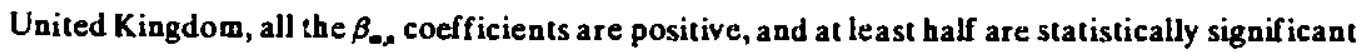
at the $1 \%$ level.

Examination of the results on $\left[1-\beta_{-, 0}\right]$ in Table 1 indicate that the nominal term structure contains substantial information about the term structure of real interest rates in most countries is quite strong. With the exception of the United Kingdom and Japan, the $\left[1-\beta_{\ldots .}\right]$ estimates are always positive, are statistically significant $90 \%$ of the time and are significant at the $1 \%$ level $80 \%$ of the time. For Japan, the evidence is somewhat mixed with two of the [ $\left.1-\beta_{\ldots,}\right]$ estimates

\footnotetext{
"This might be less true if there are significant capital and exchange controls in the economy which result in greater time-variability of the risk premiums in domestic interest rates.
} 
positive and statistically significant, while three of the estimates are negative but statistically insignificant. The term structure for the United Kingdom, on the other band, reveals absolutely no information about the term structure of real interest rates. All the $\left[1-\beta_{., 0}\right]$ estimates are statistically insignificant with t-statistics less than one in absolute value.

As was discussed in the methodology section, if equation residuals across different time borizons are correlated, more eff icient estimates can be obtained by exploiting this inf or mation with seemingly unrelated regression (SUR) estimation. Table 2, which contains the SUR estimates of the same inf lation change equations found in Table 1, indicates that SUR estimation of ten leads to large increases in efficiency .. coeff icient standard errors of ten decline by more than $50 \%$ and in one case declines by $80 \% .^{.}$

The increased eff iciency of the SUR estimates tends to strengthen the conclusions reached before. All the $\beta_{n}$, coefficients for France and the United Kingdom are now statistically significant, while five out of six are significant for Germany. Thus the SUR results provide even stronger evidence that the term structure in these countries contains substantial information about the future path of inflation.

The SUR estimates of the $\left[1-\beta_{a, d}\right]$ coefficients continue to provide strong evidence that the nominal term structure contains substantial information about the term structure of real interest rates for most countries. With the exception of the United Kingdom and Japan, almost all of the $\left[1-\beta_{\text {... }}\right]$ estimates are significantly positive at the $1 \%$ level. For Japan, all of the [1 $\beta_{\text {... }}$ estimates are positive and balf are statistically signii icant at the $5 \%$ level. The evidence for these nine countries is thus quite strong that the term structure of nominal rates reveal a great deal of inf ormation about the term structure of real rates. The results for the United Kingdom continue to tell a different story. Despite much greater precision in the coefficient estimates -

\footnotetext{
${ }^{12}$ Note, however, that in several cases, the estimated standard errors are higher in Table 2 than they are in Table 1. Even though the SUR estimates are asymptotically more efficient than OLS estimates, in small samples estimated SUR standard errors can turn out to be larger than OLS standard errors.
} 
Table 2

Seemingly Unrelated Regression (SUR) Estimates of Inflation Change Equations

$$
\pi_{\varepsilon}^{n}-\pi_{\varepsilon}^{n}-\alpha_{a, n}+\beta_{a . n}\left[i:-i_{i}^{n}\right]+\eta_{i}^{p \cdot n}
$$

\begin{tabular}{|c|c|c|c|c|}
\hline$\underset{\text { (months) }}{\operatorname{mon}}$ & $a_{n . n}$ & $\beta_{ \pm, n}$ & $\begin{array}{c}t \text {-test } \\
\text { of } \\
\beta_{0, n}=0\end{array}$ & $\begin{array}{l}t-\text { test } \\
\text { of } \\
\beta_{0, n}=1\end{array}$ \\
\hline
\end{tabular}

Country: UNITED STATES

\begin{tabular}{|c|c|c|c|c|}
\hline 3,1 & $\begin{array}{l}-0.0366 \\
(0.0786)\end{array}$ & $\begin{array}{c}0.2940 \\
(0.3900)\end{array}$ & 0.75 & 1.81 \\
\hline 6,1 & $\begin{array}{l}-0.0841 \\
(0.1366)\end{array}$ & $\begin{array}{c}0.3099 \\
(0.2000)\end{array}$ & 1.55 & $3.45^{\star \star}$ \\
\hline 12,1 & $\begin{array}{l}-0.0695 \\
(0.2307)\end{array}$ & $\begin{array}{c}0.3173 \\
(0.1335)\end{array}$ & $2.38^{*}$ & $5.12^{\star *}$ \\
\hline 6,3 & $\begin{array}{l}-0.0467 \\
(0.0741)\end{array}$ & $\begin{array}{c}0.3160 \\
(0.1714)\end{array}$ & 1.84 & $3.99^{\star \star}$ \\
\hline 12,3 & $\begin{array}{l}-0.0304 \\
(0.1887)\end{array}$ & $\begin{array}{c}0.3208 \\
(0.1429)\end{array}$ & $2.25^{\star}$ & $4.75^{\star *}$ \\
\hline 12,6 & $\begin{array}{c}0.0173 \\
(0.1279)\end{array}$ & $\begin{array}{c}0.3239 \\
(0.1397)\end{array}$ & $2.32^{\star}$ & $4.84^{\star *}$ \\
\hline
\end{tabular}

Country: CANADA

$\begin{array}{cllll}3.1 & -0.0471 & -0.1560 & -0.56 & 4.15^{\star \star} \\ & (0.0628) & (0.2788) & & \\ 6.1 & -0.1023 & -0.1570 & & \\ & (0.1251) & (0.1919) & -0.82 & 6.03^{\star \star} \\ 12.1 & -0.2327 & -0.1570 & & \\ & (0.2522) & (0.1860) & -0.84 & 6.22^{\star \star} \\ 6.3 & -0.0553 & -0.1583 & & \\ & (0.0780) & (0.2042) & -0.78 & 5.67^{\star \star} \\ 12,3 & -0.1859 & -0.1576 & & \\ & (0.2086) & (0.1783) & -0.88 & 6.49^{\star \star} \\ 12.6 & -0.1305 & -0.1572 & & \\ & (0.1447) & (0.1819) & -0.86 & 6.36^{\star \star}\end{array}$


Country: UNITED KINGDOM

$\begin{array}{ccccc}3.1 & -0.0882 & 0.8549 & 3.71^{\star \star} & 0.63 \\ 6.1 & (0.1365) & (0.2301) & & \\ & 0.0112 & 0.8600 & 4.72^{\star \star} & 0.77 \\ 12.1 & (0.2911) & (0.1821) & & \\ & 0.1412 & 0.8659 & 4.14^{\star \star} & 0.64 \\ 6.3 & (0.5685) & (0.2092) & & \\ & 0.0995 & 0.8600 & 4.67^{\star \star} & 0.76 \\ 12.3 & (0.1936) & (0.1842) & & \\ & 0.2296 & 0.8659 & 4.17^{\star \star} & 0.65 \\ 12.6 & (0.4887) & (0.2076) & & \\ & 0.1299 & 0.8681 & 4.17^{\star \star} & 0.63\end{array}$

Country: BELGIUM

$\begin{array}{ccccc}3.1 & -0.0095 & 0.0107 & 0.03 & 2.36^{\star} \\ 6.1 & (0.0676) & (0.4190) & & 4.54^{\star \star} \\ & -0.0349 & -0.0169 & -0.08 & \\ 12.1 & (0.1742) & (0.2240) & & 4.38^{\star \star} \\ & -0.1431 & -0.0151 & -0.07 & \\ 6,3 & (0.3543) & (0.2317) & & 4.62^{\star \star} \\ 12.3 & -0.0279 & -0.0189 & -0.09 & \\ & (0.1110) & (0.2207) & & 4.29^{\star \star} \\ 12.6 & -0.1359 & -0.0153 & -0.06 & \\ & (0.2998) & (0.2364) & & 4.59^{\star \star} \\ & -0.1082 & -0.0149 & -0.07 & \end{array}$


Country: FRANCE

\begin{tabular}{|c|c|c|c|c|}
\hline 3,1 & $\begin{array}{l}-0.0646 \\
(0.0766)\end{array}$ & $\begin{array}{c}0.2967 \\
(0.1399)\end{array}$ & $2.12^{\star}$ & $5.03^{\star \star}$ \\
\hline 6,1 & $\begin{array}{l}-0.1097 \\
(0.1443)\end{array}$ & $\begin{array}{c}0.2951 \\
(0.1203)\end{array}$ & $2.45^{\star}$ & $5.86^{\star \star}$ \\
\hline 12.1 & $\begin{array}{l}-0.1319 \\
(0.2686)\end{array}$ & $\begin{array}{c}0.2941 \\
(0.1010)\end{array}$ & $2.91^{\star \star}$ & $6.99^{\star \star \star}$ \\
\hline 6.3 & $\begin{array}{l}-0.0454 \\
(0.0804)\end{array}$ & $\begin{array}{c}0.2931 \\
(0.0945)\end{array}$ & $3.10^{* *}$ & $7.48^{* * *}$ \\
\hline 12,3 & $\begin{array}{l}-0.0683 \\
(0.2185)\end{array}$ & $\begin{array}{c}0.2929 \\
(0.0902)\end{array}$ & $3.25^{* \star}$ & $7.84^{* \star *}$ \\
\hline 12,6 & $\begin{array}{l}-0.0229 \\
(0.1488)\end{array}$ & $\begin{array}{c}0.2930 \\
(0.0901)\end{array}$ & $3.25^{\star \star}$ & $7.85^{\star \star}$ \\
\hline Country: & GERMANY & & & \\
\hline 3,1 & $\begin{array}{l}-0.0513 \\
(0.0588)\end{array}$ & $\begin{array}{c}0.4072 \\
(0.1555)\end{array}$ & $2.62^{* \star}$ & $3.81^{\star *}$ \\
\hline 6,1 & $\begin{array}{l}-0.1132 \\
(0.1147)\end{array}$ & $\begin{array}{c}0.4035 \\
(0.1046)\end{array}$ & $3.86^{\star \star}$ & $5.70^{\star \star}$ \\
\hline 12,1 & $\begin{array}{l}-0.2219 \\
(0.2005)\end{array}$ & $\begin{array}{c}0.4039 \\
(0.1171)\end{array}$ & $3.45^{* *}$ & $5.09^{\star *}$ \\
\hline 6,3 & $\begin{array}{l}-0.0619 \\
(0.0660)\end{array}$ & $\begin{array}{c}0.3992 \\
(0.2081)\end{array}$ & 1.92 & $2.89^{* \star}$ \\
\hline 12,3 & $\begin{array}{l}-0.1707 \\
(0.1611)\end{array}$ & $\begin{array}{c}0.4020 \\
(0.1185)\end{array}$ & $3.39^{\star \star}$ & $5.05^{* *}$ \\
\hline 12,6 & $\begin{array}{l}-0.1087 \\
(0.1141)\end{array}$ & $\begin{array}{c}0.4046 \\
(0.1555)\end{array}$ & $2.60^{\star *}$ & $3.83^{* *}$ \\
\hline
\end{tabular}


Country: ITALY

\begin{tabular}{|c|c|c|c|c|}
\hline 3.1 & $\begin{array}{l}-0.0089 \\
(0.1180)\end{array}$ & $\begin{array}{c}0.2923 \\
(0.3346)\end{array}$ & 0.87 & $2.11^{*}$ \\
\hline 6,1 & $\begin{array}{c}0.0301 \\
(0.2761)\end{array}$ & $\begin{array}{c}0.3113 \\
(0.2579)\end{array}$ & 1.21 & $2.67^{* *}$ \\
\hline 12.1 & $\begin{array}{c}0.2007 \\
(0.5723)\end{array}$ & $\begin{array}{c}0.3402 \\
(0.1743)\end{array}$ & 1.95 & $3.78^{* *}$ \\
\hline 6.3 & $\begin{array}{c}0.0431 \\
(0.1720)\end{array}$ & $\begin{array}{c}0.3305 \\
(0.1760)\end{array}$ & 1.88 & $3.80^{* *}$ \\
\hline 12,3 & $\begin{array}{c}0.2329 \\
(0.4927)\end{array}$ & $\begin{array}{c}0.3643 \\
(0.1576)\end{array}$ & $2.31^{*}$ & $4.03^{\star \star}$ \\
\hline 12,6 & $\begin{array}{c}0.2099 \\
(0.3520)\end{array}$ & $\begin{array}{c}0.4009 \\
(0.2126)\end{array}$ & 1.89 & $2.82^{\star \star}$ \\
\hline
\end{tabular}

Country: NETHERLANDS

\begin{tabular}{|c|c|c|c|c|}
\hline 3,1 & $\begin{array}{l}-0.1775 \\
(0.1031)\end{array}$ & $\begin{array}{c}0.1212 \\
(0.0670)\end{array}$ & 1.81 & $13.11^{* *}$ \\
\hline 6,1 & $\begin{array}{l}-0.2241 \\
(0.1294)\end{array}$ & $\begin{array}{c}0.1191 \\
(0.0920)\end{array}$ & 1.29 & $9.57^{\star *}$ \\
\hline 12,1 & $\begin{array}{l}-0.3361 \\
(0.2043)\end{array}$ & $\begin{array}{c}0.1194 \\
(0.0751)\end{array}$ & 1.59 & $11.73^{* *}$ \\
\hline 6,3 & $\begin{array}{l}-0.0466 \\
(0.0833)\end{array}$ & $\begin{array}{c}0.1169 \\
(0.0805)\end{array}$ & 1.45 & $10.97^{* \star}$ \\
\hline 12.3 & $\begin{array}{l}-0.1587 \\
(0.1954)\end{array}$ & $\begin{array}{c}0.1195 \\
(0.0802)\end{array}$ & 1.49 & $10.98^{\star \star}$ \\
\hline 12,6 & $\begin{array}{l}-0.1119 \\
(0.1187)\end{array}$ & $\begin{array}{c}0.1206 \\
(0.0701)\end{array}$ & 1.72 & $12.55^{\star \star}$ \\
\hline
\end{tabular}




\begin{tabular}{|c|c|c|c|c|}
\hline Country: & SWITZERLAND & & & \\
\hline 3,1 & $\begin{array}{c}0.0372 \\
(0.1119)\end{array}$ & $\begin{array}{l}-0.0996 \\
(0.2448)\end{array}$ & -0.41 & $4.49^{\star \star}$ \\
\hline 6,1 & $\begin{array}{c}0.0402 \\
(0.2374)\end{array}$ & $\begin{array}{l}-0.1261 \\
(0.2953)\end{array}$ & -0.43 & $3.81^{\star \star}$ \\
\hline 12,1 & $\begin{array}{l}-0.1601 \\
(0.3233)\end{array}$ & $\begin{array}{l}-0.1131 \\
(0.2291)\end{array}$ & -0.49 & $4.86^{\star \star}$ \\
\hline 6,3 & $\begin{array}{c}0.0009 \\
(0.1391)\end{array}$ & $\begin{array}{l}-0.1481 \\
(0.3944)\end{array}$ & -0.38 & $2.91^{\star \star}$ \\
\hline 12,3 & $\begin{array}{l}-0.1999 \\
(0.2609)\end{array}$ & $\begin{array}{l}-0.1183 \\
(0.2284)\end{array}$ & -0.52 & $4.90^{\star \star}$ \\
\hline 12,6 & $\begin{array}{l}-0.1932 \\
(0.1846)\end{array}$ & $\begin{array}{l}-0.0944 \\
(0.2493)\end{array}$ & -0.38 & $4.39^{* \star}$ \\
\hline Country: & $\mathrm{JAPAN}^{\mathrm{b}}$ & & & \\
\hline 3,1 & $\begin{array}{l}-0.2111 \\
(0.3231)\end{array}$ & $\begin{array}{c}0.4424 \\
(1.4872)\end{array}$ & 0.30 & 0.37 \\
\hline 6,1 & $\begin{array}{l}-0.2565 \\
(0.3618)\end{array}$ & $\begin{array}{c}0.3916 \\
(0.8232)\end{array}$ & 0.48 & 0.74 \\
\hline 12,1 & $\begin{array}{l}-0.3888 \\
(0.3652)\end{array}$ & $\begin{array}{c}0.3704 \\
(0.4413)\end{array}$ & 0.84 & 1.43 \\
\hline 6,3 & $\begin{array}{l}-0.0518 \\
(0.0921)\end{array}$ & $\begin{array}{c}0.3409 \\
(0.2203)\end{array}$ & 1.55 & $2.99^{\star \star}$ \\
\hline 12,3 & $\begin{array}{l}-0.1926 \\
(0.1881)\end{array}$ & $\begin{array}{c}0.3379 \\
(0.2431)\end{array}$ & 1.39 & $2.72^{\star *}$ \\
\hline 12,6 & $\begin{array}{l}-0.1412 \\
(0.1320)\end{array}$ & $\begin{array}{c}0.3360 \\
(0.2421)\end{array}$ & 1.39 & $2.74^{* \star}$ \\
\hline
\end{tabular}

$\pi_{1}^{*}-\pi_{1}^{*}=$ difference between the $m-p e r i o d$ inflation rate from time 1 to $1+m$ and the $n-p e r i o d$ inflation rate from $\downarrow$ to $t+\pi . i_{i}^{*}-i_{i}^{*}=$ difference between the $m$-period nominal interest rate and the $n$ period nominal interest rate at time $\$$. Standard errors of coefficients in parentheses. SE = standard error of the regression. ${ }^{*}=$ significant at the $5 \%$ level. ${ }^{* *}=$ significant at the $1 \%$ level.

The sample period for Japan starts in October 1975, the first date that data is available. 
- the standard errors of half the coefficients decline by over $50 \%$ as a result of using SUR estimation -- none of the $\left[1-\beta_{m,}\right]$ coefficients is statistically significant; indeed, none even has a $t$ statistic exceeding one. The evidence is thus even stronger that the U.K. differs from other countries in an important respect: its term structure of nominal interest rates contains no inf ormation about its term structure of real interest rates.

\section{A. Interpretation}

Under the assumption of rational expectations, the interpretation of the inflation-change, forecasting equation $\beta_{\ldots, n}$ is quite straightforward. Following Fama (1984) and Hardouvelis (1988), $\beta_{m, a}$ can be derived to be:

$$
\beta_{n, 0}=\frac{\tilde{\sigma}^{2}+\rho \tilde{\sigma}}{1+\tilde{\sigma}^{2}+2 \rho \tilde{\sigma}}
$$

where,

$\tilde{\sigma} \quad=\sigma\left[E_{1}\left(\pi_{i}^{*}-\pi_{i}^{*}\right)\right] / \sigma\left[r_{i}^{*}-r r_{i}^{*}\right]=$ the ratio of the standard deviation of the expected inflation change to the standard deviation of the slope of the real term structure,

$\rho=\quad$ the correlation between the expected inflation change, $\mathrm{E}_{1}\left(\pi_{;}^{*}-\pi_{;}^{*}\right)$, and the slope of the real term structure, $\mathbf{r r}_{t}^{*}-\mathbf{r r}_{t^{*}}{ }^{13}$

This expression is derived by writing down the standard formula for the projection equation coefficient $\beta_{1,2}$, and recognizing that the covariance of the inflation forecast error with $\mathrm{rr}_{1}-\mathrm{rr}_{\mathrm{t}}$ equals zero given rational expectations.

\footnotetext{
"Note that $\tilde{\sigma}$ and $\rho$ are constructed from unconditional variances and covariances.
} 
The equation above indicates that $\beta_{a, 0}$ is determined by how variable the expected inflation change is relative to the variability of the slope of the real term structure [represented by $\tilde{\sigma}$, the ratio of the standard deviations of $E_{1}\left(\pi_{t}^{m}-\pi_{t}^{m}\right)$ and $\left.\left(r r_{t}^{m}-t r_{t}\right)\right]$, as well as by the correlation of the expected inflation change with the real term structure slope $(\rho)$. Differences in the correlation and relative variation of expected inflation and the real term structure slope in the ten countries, possibly the result of different monetary regimes, will thus produce different $\beta_{m, n}$ and hence different conclusions about the information in the term structure abou the future path of inflation. Figure 1 shows how $\theta_{\mathrm{n}, \mathrm{d}}$ varies with $\tilde{\sigma}$ and $\rho$.

In order to understand why the $\hat{\beta}_{n, 0}$ differ across countries, we calculate estimated values of $\tilde{\sigma}$ and $\rho$ using the procedure outlined in Mishkin (1981), in which estimates of the real term structure spreads, $\mathrm{rr}_{1}^{\mathrm{a}}-\mathrm{rr}_{\mathrm{t}}^{\mathrm{a}}$, are obtained from fitted values of regressions of the ex-post real rate differentials on past inflation changes and past interest rate spreads." Then the estimated expected inflation change is calculated from the following definitional relationship,

$$
E_{t}\left(\pi_{t}^{m} \cdot \pi_{t}^{n}\right)=i_{t}^{m}+i_{t}^{*} \cdot\left(r r_{1}^{n} \cdot r r_{t}^{n}\right)
$$

Finally estimates of $\tilde{\sigma}$ and $\rho$ a re calculated from the estimated $E_{1}\left(\pi_{1}^{m}-\pi_{f}^{*}\right)$ and $\left(r r_{1}^{m}-r r_{r}\right)$.

With the exception of France, the estimated values of $\rho$ for the other countries in Table 1 were quite negative, averaging around -0.8 and typically ranging from $-0.510-0.95$. These values of $\rho$ follow from the fact that with the exception of France, the variability of the slope of the nominal term structure, $i_{1}^{*}-i_{1}$, is very small relative to the variability of the slope of the real term structure, $r r_{t}^{*}$ - $r r_{1}$, and thus, as is evident in equation (6) above, the correlation beiween $E_{1}\left(\pi_{1}^{m}\right.$ $\left.\pi_{r}^{*}\right)$ and $r r_{i}^{*}-r_{2}^{*}$ must necessarily be quite negative. As can be seen in Figure 1, with estimates ol

\footnotetext{
"The estimates described in the text were generated from OLS regressions in which the expost real rate differential, eprrm - eprr, was regressed on $i_{t}^{m}-i_{n}^{n}$, this differential lagged twelve months, fifteen months and twenty-four months, and on the inflation change $\left(\pi^{\circ}-\pi^{\circ}\right)$ lagged twelve months and twenty-four months. 1 also experimented with other choices of lags and the estimated values of $\sigma$ and $\rho$ were robust to different specifications of the regression equations.
} 


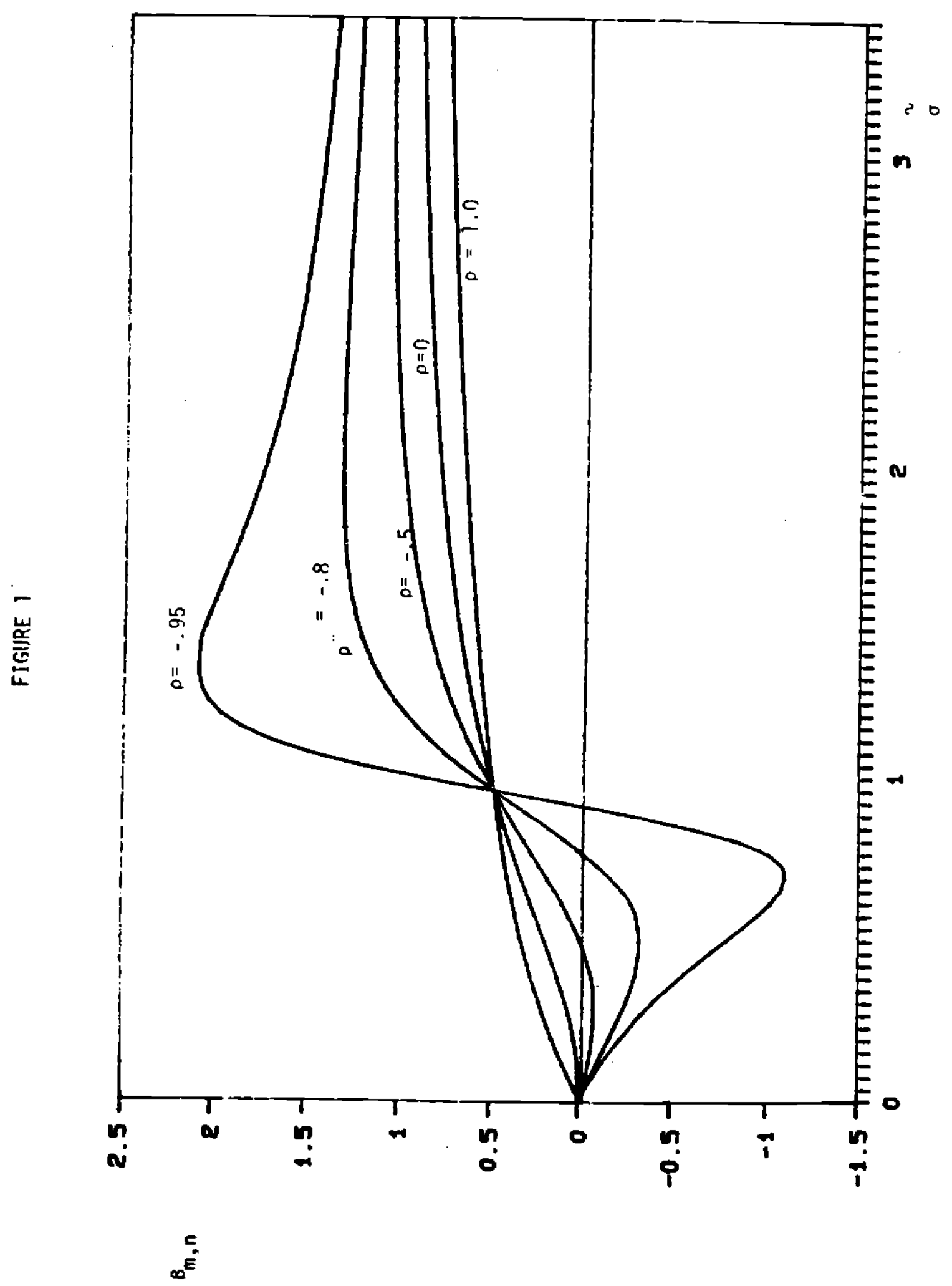


$\rho$ around -0.8 , if the variability of expected inflation changes is sufficiently less than the variability of the real term structure slope so that $\tilde{\sigma}$ is less than 0.8 , then $\theta_{a, n}$ will not be above zero.

Low estimated values of $\tilde{\sigma}$ which are less than 0.8 are exactly what we find for all the horizons in countries such as Canada, Belgium, Netherlands and Switzerland. These low values of $\tilde{\sigma}$ and very negative values of $\rho$ thus explain why we do not find significant positive $\hat{\beta}_{\mathrm{m}, \mathrm{n}}$ coefficients for these countries.

Research that suggests that term premiums undergo substantial fluctuations over time's provide a rationale for the low values of $\tilde{\sigma}$ and the resulting inability of the term structure to provide information about the future path of inflation. Variation in the slope of the real term structure can be attributed to the variation of term premiums over time as well as changes in the average of expected one-perind real interest rates over the next $m$-periods versus the next $n$ periods. High variation in these term premiums will then produce high variation in the slope of the real term structure and make it more likely that the variation of the real term structure slope will dominate the variation of expectedfuture inflation changes. The outcome of substantial time variation of term premiums will then be a low $\tilde{\sigma}$ and a low $\hat{\beta}_{0,0}$ estimate, so that the term structure will provide little inf ormation about future inflation changes. The flip side of this argument is that substantial variation in term premiums, which produces low $\hat{\beta}_{\mathrm{n}, \mathrm{*}}$ estimates, lead to the linding that the term structure of nominal interest rates contains a great deal of information about the term structure of real interest rates. ${ }^{10}$

'Jones and Roley (1983), Mankiw and Summers (1984), Shiller, Campbell and Schoenholtz (1983), and Startz (1982).

${ }^{16}$ The same reasoning in this paragraph provides a more rigorous explanation of why results using eurorates indicate that there is less information in the term structure about the path of future inflation than when T-bill data is used as in Mishkin (1988b). As explained in the text, eurodollar rates embody a default risk premium not found in $T$-bill rates. The additional risk premium in euro rates can thus lead to greater variation in the real term structure slope which leads to smaller $\tilde{\sigma}$ and hence lower $\hat{\beta}_{\mathrm{a}}$, estimates. 
In the case of Germany, the variability of expected future inflation changes is close to the variability of the real term structure slopes and this explains why the estimated $\hat{\beta}_{-,}$coefficients are positive and close to 0.5 . In the case of the United States and ltaly, for the short horizons in which $m$ is less than twelve months, $\tilde{\sigma}$ is quite low; but as the m-horizon lengthens the variability of the real term structure slope declines relative to the variability of the expected inflation changes so that $\tilde{\sigma}$ rises above 0.9 . The result is that the $\hat{\beta}_{\text {., }}$ coefficients get larger at longer maturities, and this is why results for both Italy and the U.S. suggest that there is significant inf ormation in the longer maturity term structure about future inflation changes.

In Tables 1 and 2 the results for the United Kingdom stand out because it bas the highest values of $\hat{\beta}_{., a}$ and is the only country for which we cannot reject the null hypothesis that $\beta_{\ldots .,}=1$. These findings are readily explained by the fact that the U.K. consistently has the highest variability of expected future inflation changes relative to the variability of the real term structure slopes. The estimated $\tilde{\sigma}$ 's which range from 1.0 to 1.1 interact with $\rho$ 's which are around -0.9 to produce $\hat{\beta}_{-, \mathrm{a}}$ coeff icients close to 1.0 .

The estimated values of $\rho$ for France are quite different than for the other countries. In contrast to all the other countries studied here, France has greater variation in the slope of the nominal term structure than in the slope of the real term structure. The result is estimates of $\rho$ that are generally around zero. Thus, even though the variability of expected future inflation changes for France are less than the variability of real term structure slopes, so that $\tilde{\sigma}$ 's are less than 0.85 , Figure 1 shows us that the $\beta_{\ldots,+}$ will be positive but less than 0.5 , which is exactly what we find in Tables 1 and 2. The fact that France displays large variation in the nominal term structure slope (the explanatory variable) explains the statistical signif icance for the French $\hat{\beta}_{w}$. estimates because in the regressions it leads to high variability of the explanatory variable relative to the variability of the dependent variable."

\footnotetext{
"This f act also explains why the French regressions have the highest $\mathbf{R}^{\text {"'s }}$ because $\mathbf{R}^{1}$ equals $\hat{\beta}^{2}$ times the ratio of the variance of the explanatory variable to the variance of the dependent variable.
} 


\section{Conclusions}

This paper provides evidence on what the term structure (for maturities of twelve months or less) tells us about future inflation in ten OECD countries. The empirical results on the information in the term structure contrast with those in previous research which find that the level of interest rates help forecast the future level of inflation. Instead they indicate that for the majority of the countries in the sample, the term structure does not contain a great deal of inf ormation about the future path of inflation. The results for France, the United Kingdom and Germany tell a different story, however. In these countries the term structure contains a highly significant amount of information about future changes in inflation.

The analy sis in this paper suggests that central banksfor most of the countries studied here should exercise some caution in using the term structure of interest rates as a guide for assessing inflationary pressures in the economy, as is currently under consideration by the U.S. central bank. There are two reasons for this conclusion. First, the empirical evidence here indicates that although there is significant information in the term structure about the future path of inflation for a few of the countries, this is not a result that is true in general.

Second, as the interpretation of the results indicates, the $\beta$-regression coefficients are sensitive to the relative variability of expected future inflation changes and real term structure slopes, as well as to the correlation of these two variables. Any change in the method of conducting monetary policy, such as focusing on the term structure as a guide to monetary policy, is likely to change the correlation and relative variability of expected f uture inf lation changes and real term structure slopes, thus causing the regression coefficients to change in the inflationchange forecasting equation. Thus the forecasting ability of the term structure for the path of future inflation could change dramatically, making the term structure a poor guide for monetary policy. This is, of course, just another example of the Lucas (1976) critique. 
The empirical evidence does reveal, however, that for every country studied except the United Kingdom, there is a great deal of inf ormation in the term structure of nominal interest rates about the term structure of ceal interest rates. This finding is an extremely usef ul one because it suggests that for most countries researchers can examine observable data on the nominal term structure to provide them with information about the behavior of the real term structure. 


\section{References}

Campbell, John Y. and Shiller, Robert J., "Cointegration and Tests of Present Value Models," Journal of Political Economy 95 (October 1987): 1062-1088.

Fama, Eugene F., "Short Term lnterest Rates as Predictors of Inflation," American Economic Bexiew 65 (1975): 269-82. 509.528 .

-, "The Inf or mation in the Term Structure," Journal of FinancialEconomics 13 (1984):

and Bliss, Robert R., "The lnformation in Long-Maturity Forward Rates," American Economic Review, 77 (September 1987): 680-92.

and Gibbons, Michael R., "Inflation, Real Returns and Capital lnvestment," Lournal of Monetary Economics 9 (1982): 297-324.

Fisher, lrving, The Theory of Interest (New York :Macmillan 1930).

Hansen, Lars P., "Large Sample Properties of Generalized Method of Moments Estimators," Econometrica 50: 1029-54

Hansen, Lars, and Hodrick, Robert, "Forward Exchange Rates as Optimal Predictors of Future Spot Rates," Journal of Political Economy 88 (1980): 829-53.

Hardouvelis, Gikas A., "The Predictive Power of the Term Structure During Recent Monetary Regimes," Journal of Finance 43 (June 1988): 339-56.

Huizinga, John and Mishkin, Frederic S., "Inflation and Real lnterest Rates on Assets with Different Risk Characteristics," Journal of Finance 39 (1984): 699-712.

"Monetary Policy Regime Shifts and the Unusual Behavior of Real Interest Rates, "Carnegie-Rochester Conference Series on Public Policy, 24 (Spring 1986): 231-74.

Jones, David S., and Roley, V. Vance, "Rational Expectations and the Expectations Model of the Term Structure: A Test Using Weekly Data," lournal of Monetary Economics 12 (September 1983):

Lucas, Robert E. Jr., "Econometric Policy Evaluation: A Critique," in Karl Brunner and Allan H. Meltzer, eds., The Phillips Curve and Labor Markets, Carnegie-Rochester Conf erence Series on Public Policy, 1 (Amsterdam: North Holland, 1976): 19-46.

Mankiw, N. Gregory and Summers, Lawrence H., "Do Long-Term Interest Rates Overreact to Short-Term Interest Rates?" Brookings Papers on Economic Activity, (1984:1): 223-242.

Mishkin, Frederic S., "The Real Rate of Interest: An Empirical lnvestigation," The Cost and Consequences of Inflation, Carnegie-Rochester Conference Series on Public Policy, 15 (1981): 151-200. 
"The Real Interest Rate: A Multi-Country Empirical Study," Canadian Journal of Economics 17 (May 1984): 283-311.

..................., "The Inf ormation in the Term Structure: Some Further Results, "f orthcoming in the Lournal of Applied Econometrics 3 (October-December 1988): 307-14.

...................... What Does the Term Structure Tell Us About Future Inflation," NBER Working Paper \#2626, June 1988 (b).

Nelson, Chartes R., and Schwert, G. William, "Short-Term Interest Rates as Predictors of In . flation: On Testing the Hypothesis that the Real Rate of Interest is Constant." American Economic Review, 67 (1977): 478-86.

Newey, W. and West Kenneth, "A Simple, Positive Definite, Heteroskedasticity and Autocorrela tion Consistent Covariance Matrix," Econometrica 55 (1987): 703-708.

Shiller, Robert J., Campbell, John Y., and Schoenholtz, Kermit L., "Forward Rates and Future Policy: Interpreting the Term Structure of Interest Rates," Brookings Papers on Economic Activity (1983:1): 173-217.

Startz, Richard, `Do Forecast Errors or Term Premia Really Make the Difference Between Long and Short Rates?" Journal of Financial Economics 10 (1982): 323-329.

White, Halbert, "A Heteroskedasticity-Consistent Covariance Matrix Estimator and Direct tests for Heteroskedasticity," Econometrica 48 (1980): 817-38. 